\title{
Carbon partitioning within meiobenthic nematode communities in the Exe Estuary, UK
}

\author{
Andrew D. Kennedy* \\ Department of Biological Sciences, Hatherly Laboratories, University of Exeter, Exeter EX4 4PS, United Kingdom
}

\begin{abstract}
Acknowledging the importance of free-living nematodes to the trophic dynamics of marine benthic systems, a study was performed in the Exe Estuary, southwest England, to estimate the magnitude and partitioning of carbon flow through Wieser's (1953; Ark. Zool. 4: 439-484) classification of nematode feeding groups. Quarterly sampling over a 12 mo period of mud and sand substrata revealed mean nematode densities of $2.06 \times 10^{6}$ and $1.69 \times 10^{6} \mathrm{~m}^{-2}$ respectively, with highest populations in July. Species identities and dimensions were determined using image processing techniques: 21 species were recorded from the mud habitat and 30 species from the sand. Non-selective deposit feeders (Group 1B) dominated the mud community and epigrowth feeders (Group 2A) the sand. Literature conversion factors were used to calculate respiration, production and carbon consumption by each of the feeding groups; a model describing the partitioning of carbon flow was thus achieved. The model reveals that, despite the numerical dominance of mud and sand communities by Groups $1 \mathrm{~B}$ and 2A respectively, in terms of carbon flow the omnivore-predators (Group 2B) play an important role. Whole nematode community production estimates of 1.4 and $1.0 \mathrm{~g} \mathrm{C} \mathrm{m}^{-2} \mathrm{yr}^{-1}$ are exceeded by the carbon consumption of this group, viz. 2.0 and $3.1 \mathrm{~g} \mathrm{C} \mathrm{m}^{-2} \mathrm{yr}^{-1}$ Assuming that omnivore-predator nematodes derive a significant proportion of their diet from Metazoa, the model reveals that nematodes play a more important role in the 'small food web' than has hitherto been acknowledged.
\end{abstract}

KEY WORDS: Trophic pathways - Nematoda Feeding groups $\cdot$ Consumption - Small food web

\section{INTRODUCTION}

Meiofauna comprise one of the most numerous groups of organisms in marine soft bottom communities. In littoral sediments, densities generally range from $10^{5}$ to $10^{7}$ individuals $\mathrm{m}^{-2}$ (Tietjen 1969, Coull \& Bell 1979j. Although their biomass is small, according to the basic principle that metabolism is a function of body surface area rather than of body weight, their energetic significance is relatively great. Gerlach (1971). Fenchel (1978) and Kuipers et al. (1981) all emphasize the importance of meiofauna in marine energetics.

The trophic position of meiofauna in benthic communities is a subject of considerable controversy. An

\footnotetext{
- Present address: Division of Fisheries, CSIRO Marine Laboratories, PO Box 20, North Beach, Western Australia 6020 , Australia
}

open question is the extent to which they are either a self-contained 'energy sink' or, alternatively, facilitate the transfer of primary food resources up the size spectrum, ultimately to commercially important food species for man. Meiofaunal populations may be controlled either by internal predation by carnivorous meiofauna or by infaunal predation by macrobenthos and by small epibenthic predators. No conclusion has yet been reached as to which trophic pathway accounts for a greater proportion of meiofaunal yield.

This paper describes a combined field and modelling approach used to assess the potential of a single meiofaunal phylum to contribute to the energy sink hypothesis. Nematoda is the most ubiquitous, abundant and diverse meiofaunal component of most benthic communities (Platt \& Warwick 1980, Warwick 1981, Heip et al. 1982, Vranken \& Heip 1986, Vranken et al. 1986); it is thus likely to play an important role in marine benthic trophic dynamics. 
Nematodes possess a wide range of buccal structures which are believed to reflect their diet (Wieser 1953). The purpose of the study was to calculate total nematode community consumption and its partitioning between different feeding modes. Of particular interest were the omnivore-predator feeding nematodes since this group, through preying on other metazoa, is expected to play a central role in the small food web.

\section{MATERIALS AND METHODS}

The investigation was carried out in the Exe Estuary, southwest England (Fig. 1). A detailed description of the physical, chemical and biological nature of the estuary is given by Boalch (1980). Earlier work on the trophic dynamics of its meiobenthos is described by Warwick (1982), Gee (1987) and Kennedy (1993).

At quarterly intervals between October 1989 and July 1990, 12 sediment samples were taken on a stratified random basis from 2 contrasting intertidal sample

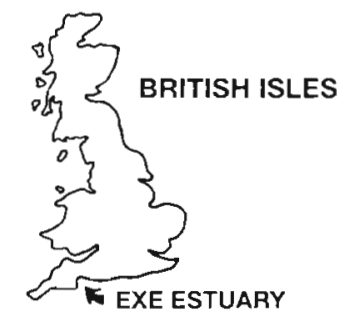

SUBSTRATUM TYPE

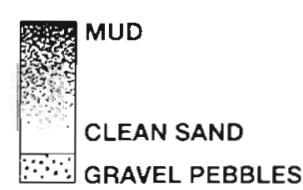

Fig. 1. Map of Exe Estuary (SW Eng. land), showing location of sample sites
Table 1 Population densities of nematodes at sand and mud sites in the Exe Estuary (ind. $\times 10^{6} \mathrm{~m}^{-2}$ sediment surface)

\begin{tabular}{lccccc} 
& January & April & July & October & (Mean) \\
\hline Mud site & $2.51 \pm 0.04$ & $1.36 \pm 0.13$ & $2.90 \pm 0.17$ & $1.47 \pm 0.12$ & $(2.06)$ \\
Sand site & $1.37 \pm 0.02$ & $1.85 \pm 0.04$ & $2.42 \pm 0.08$ & $1.10 \pm 0.02$ & $(1.69)$ \\
\hline
\end{tabular}

stations, one mud and one sand. Sampling was achieved using simple corers constructed from surgical syringes. To reflect the greater abundance of meiofauna in mud than in sand, syringes of dimensions $50 \mathrm{~mm}$ length by $16 \mathrm{~mm}$ internal diameter were used for sampling the mud substratum while syringes of dimensions $100 \mathrm{~mm}$ length by $26 \mathrm{~mm}$ diameter were used for the sand. These dimensions conform with the recommendations of McIntyre \& Warwick (1984). The samples were fixed using $10 \%$ formalin and preserved in $4 \%$ formalin for laboratory analysis. Meiofauna were extracted using a modified version of the Ludox density separation technique (Jonge \& Bouwman 1977) described by Austen (1986). Extracted meiofauna were slide-mounted in glycerol for subsequent microscopy examination.

The meiofauna thus obtained were analysed for 2 criteria: (1) the total number of nematodes present, and (2) the species identity, feeding group and dimensions of the first 50 nematodes encountered for each quarter from each sample site by random scanning of the slides. Dimensions were determined using a KONTRON-M15 image processing system; each measurement was repeated 3 times and the mean taken as the best estimate.

\section{RESULTS AND ANALYSIS}

The population densities of nematodes calculated from samples for each quarter at the 2 sample sites are given in Table 1 . The relative abundance of nematode species encountered by random scanning is given in Table 2. Their allocation to trophic groups is included. For the purpose of this study, Wieser's (1953) feeding classification is used. This divides nematodes into (1A) selective deposit feeders, (1B) non-selective deposit feeders, (2A) epigrowth feeders, and (2B) omnivorepredators, on the basis of buccal morphology.

Individual nematode volumes were calculated using the formula $V=K L W^{2}$, where $V=$ volume (nl), $K$ is a constant (530), and $L$ and $W$ are respectively length and maximum width $(\mathrm{mm})$. The derivation of this formula is explained by Warwick \& Price (1979). This technique was felt to be more accurate than that of Bovée (1987), which takes no account of nematode 
Table 2. Relative abundance of nematode species (expressed as percentage of total). Feeding groups also shown

\begin{tabular}{|c|c|c|c|c|c|c|c|}
\hline Number & Species & January & April & July & October & Mean & $\begin{array}{l}\text { Feeding } \\
\text { group }\end{array}$ \\
\hline \multicolumn{8}{|l|}{ Mud site } \\
\hline 1 & Metalinhomoeus filiformis & 16 & 48 & 48 & 30 & 35.5 & $1 \mathrm{~B}$ \\
\hline 2 & Sabatieria pulchra & 46 & 36 & 8 & 26 & 29.0 & $1 \mathrm{~B}$ \\
\hline 3 & Ptycholaimellus ponticus & 8 & 0 & 12 & 14 & 8.5 & $2 \mathrm{~A}$ \\
\hline 4 & Viscosia viscosa & 12 & 4 & 2 & 2 & 5.0 & $2 \mathrm{~B}$ \\
\hline 5 & Dichromadora cephalata & 2 & 2 & 6 & 2 & 3.0 & $2 \mathrm{~A}$ \\
\hline 6 & Halalaimus gracilis & 2 & 2 & 4 & 4 & 3.0 & $1 \mathrm{~A}$ \\
\hline 7 & Anoplostoma viviparum & 2 & 2 & 2 & 4 & 2.5 & $1 \mathrm{~B}$ \\
\hline 8 & Dichromadora geophila & 2 & 0 & 8 & 0 & 2.5 & $2 \mathrm{~A}$ \\
\hline 9 & Sphaerolaimus hirsutus & 4 & 0 & 0 & 4 & 2.0 & $2 \mathrm{~B}$ \\
\hline 10 & Metachromadora vivipara & 0 & 0 & 4 & 2 & 1.5 & $2 \mathrm{~A}$ \\
\hline 11 & Calyptronema maxweberi & 0 & 2 & 0 & 2 & 1.0 & $2 \mathrm{~B}$ \\
\hline 12 & Camacolaimus barbatus & 0 & 2 & 0 & 2 & 1.0 & $2 \mathrm{~A}$ \\
\hline 13 & Praeacanthonchus punctatus & 0 & 0 & 2 & 2 & 1.0 & $2 \mathrm{~A}$ \\
\hline 14 & Thalassoalaimus tardus & 2 & 0 & 0 & 2 & 1.0 & $1 \mathrm{~A}$ \\
\hline 15 & Adoncholaimus thalassophygas & 0 & 2 & 0 & 0 & 0.5 & $2 \mathrm{~B}$ \\
\hline 16 & Antomicron elegans & 2 & 0 & 0 & 0 & 0.5 & $1 \mathrm{~A}$ \\
\hline 17 & Chromadora macrolaima & 0 & 0 & 0 & 2 & 0.5 & $2 \mathrm{~A}$ \\
\hline 18 & Daptonema normandicum & 0 & 0 & 0 & 2 & 0.5 & $1 B$ \\
\hline 19 & Hypodontolaimus balticus & 0 & 0 & 2 & 0 & 0.5 & $2 \mathrm{~A}$ \\
\hline 20 & Onyx sagittarius & 0 & 0 & 0 & 2 & 0.5 & $2 \mathrm{~A}$ \\
\hline 21 & Paralinhomeus tenuicaudatus & 2 & 0 & 0 & 0 & 0.5 & $1 \mathrm{~B}$ \\
\hline 22 & (Unidentified species) & $(0)$ & $(2)$ & $(2)$ & $(0)$ & $(1.0)$ & $(-)$ \\
\hline \multicolumn{8}{|l|}{ Sand site } \\
\hline 1 & Chromadora nudicapitata & 12 & 2 & 20 & 10 & 11.0 & $2 \mathrm{~A}$ \\
\hline 2 & Leptolaimus ampullaceus & 6 & 12 & 4 & 18 & 10.0 & $1 \mathrm{~B}$ \\
\hline 3 & Microlaimus spp. & 10 & 14 & 8 & 6 & 9.5 & $2 \mathrm{~A}$ \\
\hline 4 & Enoplolaimus proprinquus & 10 & 8 & 8 & 6 & 8.0 & $2 \mathrm{~B}$ \\
\hline 5 & Xyala striata & 10 & 6 & 8 & 8 & 8.0 & $1 \mathrm{~B}$ \\
\hline 6 & Neochromadora tricophora & 6 & 8 & 10 & 4 & 7.0 & $2 \mathrm{~A}$ \\
\hline 7 & Pomponema sedecima & 6 & 4 & 4 & 8 & 5.5 & $2 \mathrm{~A}$ \\
\hline 8 & Neochromadora tecta & 4 & 6 & 4 & 4 & 4.5 & $2 \mathrm{~A}$ \\
\hline 9 & Gammanema conicauda & 2 & 6 & 4 & 2 & 3.5 & $2 \mathrm{~B}$ \\
\hline 10 & Onyx perfectus & 2 & 6 & 0 & 4 & 3.0 & $2 \mathrm{~A}$ \\
\hline 11 & Sigmophoranema litorale & 0 & 0 & 4 & 4 & 2.0 & $2 \mathrm{~A}$ \\
\hline 12 & Theristus denticulatus & 4 & 2 & 0 & 2 & 2.0 & $1 \mathrm{~B}$ \\
\hline 13 & Ascolaimus elongatus & 2 & 2 & 0 & 2 & 1.5 & $1 B$ \\
\hline 14 & Trefusia longicaudata & 2 & 2 & 0 & 2 & 1.5 & $1 \mathrm{~A}$ \\
\hline 15 & Enoploides brunetti & 0 & 0 & 2 & 2 & 1.0 & $2 \mathrm{~B}$ \\
\hline 16 & Eumorpholaimus sabuliculous & 0 & 4 & 0 & 0 & 1.0 & $1 \mathrm{~B}$ \\
\hline 17 & Chromadorella filiformis & 0 & 0 & 4 & 0 & 1.0 & $2 \mathrm{~A}$ \\
\hline 18 & Chromadorina germanica & 0 & 0 & 0 & 4 & 1.0 & $2 \mathrm{~A}$ \\
\hline 19 & Chromodorita tenuis & 0 & 0 & 2 & 2 & 1.0 & $2 \mathrm{~A}$ \\
\hline 20 & Oncholaimus brachycercus & 2 & 0 & 2 & 0 & 1.0 & $2 \mathrm{~B}$ \\
\hline 21 & Sigmophoranema rufum & 2 & 0 & 0 & 2 & 1.0 & $2 \mathrm{~A}$ \\
\hline 22 & Adoncholaimus fuscus & 0 & 2 & 0 & 0 & 0.5 & $2 \mathrm{~B}$ \\
\hline 23 & Enoplolaimus denticulatus & 0 & 2 & 0 & 0 & 0.5 & $2 \mathrm{~B}$ \\
\hline 24 & Gerlachius novusetosus & 2 & 0 & 0 & 0 & 0.5 & $1 \mathrm{~A}$ \\
\hline 25 & Ptycholaimellus ponticus & 0 & 0 & 2 & 0 & 0.5 & $2 \mathrm{~A}$ \\
\hline 26 & Stephanolaimus elegans & 0 & 0 & 0 & 2 & 0.5 & $2 \mathrm{~A}$ \\
\hline 27 & Tarvaia angusta & 0 & 2 & 0 & 0 & 0.5 & $1 \mathrm{~A}$ \\
\hline 28 & Trichotheristus mirabilis & 0 & 2 & 0 & 0 & 0.5 & $1 \mathrm{~B}$ \\
\hline 29 & Viscosia cobii & 0 & 0 & 0 & 2 & 0.5 & $2 \mathrm{~B}$ \\
\hline 30 & Viscosia viscosa & 0 & 0 & 2 & 0 & 0.5 & $2 B$ \\
\hline 31 & (Unidentified species) & $(18)$ & $(10)$ & (12) & $(6)$ & $(11.5)$ & $(-)$ \\
\hline
\end{tabular}


Table 3. Integrated biomass of feeding groups $\left(\mathrm{mg} \mathrm{m}^{-2}\right.$ sedi. ment surface)

\begin{tabular}{|crrrr}
\hline & $1 \mathrm{~A}$ & \multicolumn{1}{c}{$1 \mathrm{~B}$} & $2 \mathrm{~A}$ & \multicolumn{1}{c}{$2 \mathrm{~B}$} \\
\hline Mud site & & & & \\
January & 11.49 & 217.86 & 41.96 & 240.14 \\
April & 2.07 & 149.46 & 7.54 & 80.89 \\
July & 9.01 & 225.11 & 139.79 & 35.28 \\
October & 6.73 & 112.02 & 57.29 & 70.25 \\
(Mean) & $(7.32)$ & $(176.11)$ & $(61.65)$ & $(106.64)$ \\
Sand site & & & & \\
January & 3.92 & 32.31 & 64.04 & 91.23 \\
April & 7.75 & 49.75 & 69.43 & 171.96 \\
July & 3.39 & 32.60 & 130.54 & 202.81 \\
October & 1.57 & 32.30 & 47.56 & 72.96 \\
(Mean) & $(4.16)$ & $(36.74)$ & $(77.89)$ & $(134.74)$ \\
\hline
\end{tabular}

width, and that of Andrassy (1956), which assumes a conical tail shape. Nematode volume was converted into biomass by assuming a specific gravity of 1.13 (Wieser 1960), an estimate of dry weight as $22.5 \%$ of wet weight [midway between the values of $20 \%$ and $25 \%$ reported by Myers (1967) and Wieser (1960)], and carbon content as constituting $40 \%$ of dry mass (Steele 1974, Feller \& Warwick 1988). The integrated biomass of feeding groups per quarter per $\mathrm{m}^{2}$ of sediment surface at each site are shown in Table 3.

Nematode community respiration was estimated using literature values for the regression of size on oxygen consumption. These were derived by plotting respiration rate (measured using Cartesian Diver or oxygen electrode techniques) against body volume, and expressing the results in the form: $R=a V^{b}$ where $R=$ oxygen consumption, $V=$ volume, and $a$ and $b$ are constants. As for other poikilotherms, $b$ is taken as being 0.75 (Teal \& Wieser 1966). The value for $\log a$ is considered to be an indication of metabolic intensity (Schiemer \& Duncan 1974) and to correlate with feeding group (Wieser \& Kanwisher 1961, Teal \& Wieser 1966). Warwick \& Price (1979) provide estimates for 48 nematode species based on a synthesis of experimental data and literature values. By using their mean values assigned for each feeding group (Table 4)

Table 4. $\log$ a values for nematode feeding groups. Data derived from Warwick \& Price (1979)

\begin{tabular}{|lr|}
\hline Feeding group & Log $a \pm 1 \mathrm{SE}$ \\
\hline Selective deposit feeders (1A) & $-0.344 \pm 0.095$ \\
Non-selective deposit feeders (1B) & $0.018 \pm 0.059$ \\
Epigrowth feeders (2A) & $-0.258 \pm 0.076$ \\
Predator-omnivores (2B) & $0.101 \pm 0.076$ \\
\hline
\end{tabular}

the oxygen requirements at $20^{\circ} \mathrm{C}$ of the nematodes recorded in this study were calculated.

To convert these figures into field values, sediment temperatures recorded at the time of meiofaunal sampling and a $Q_{10}$ of 1.8 were used. The $Q_{10}$ figure is intermediate between reported values for nematodes (see Wieser \& Schiemer 1977, Zaika \& Makarova 1979, Atkinson 1980, Price \& Warwick 1980). To produce an estimate of average daily temperature, $2^{\circ} \mathrm{C}$ has been deducted from the recorded sediment temperatures to compensate for sampling always being performed during daylight hours. By substituting these values into the classical $Q_{10}$ equation (Hoff 1896) the total oxygen consumed by each group was estimated. Oxygen respired was converted into carbon metabolized using the relationship $1 \mathrm{ml} \mathrm{O}_{2}$ respired $=0.4 \mathrm{mg}$ carbon metabolized (Crisp 1984) (Table 5).

Table 5. Summary of nematode community energetics (all values $\mathrm{mg} \mathrm{C} \mathrm{m} \mathrm{m}^{-2} \mathrm{yr}^{-1}$ ) for the 4 feeding groups

\begin{tabular}{|lcrrr|}
\hline Parameter & 1A & $1 \mathrm{~B}$ & $2 \mathrm{~A}$ & \multicolumn{1}{c}{$2 \mathrm{~B}$} \\
\hline Mud site & & & & \\
$\quad$ Respiration & 34.9 & 1660 & 380 & 746 \\
$\quad$ Production & 29.3 & 704 & 247 & 427 \\
$\quad$ Consumption & 107 & 3940 & 1040 & 1960 \\
Sand site & & & & \\
$\quad$ Respiration & 20.7 & 376 & 505 & 1340 \\
$\quad$ Production & 16.6 & 147 & 312 & 539 \\
Consumption & 62.3 & 872 & 1360 & 3120 \\
\hline
\end{tabular}

To calculate nematode production the $P / B$ technique was employed (Waters 1977). This relies upon the relatively predictable relationship between annual production and mean annual biomass of a population (Dickie 1972, Banse \& Mosher 1980), a function of its life-history characteristics. For the purpose of this study a $P / B$ ratio of 10 was employed, considered adequate by Bodin et al. (1984) for the assessment of meiofaunal production. The value conforms with the findings of von Thun (1968) and Warwick \& Price (1979) and with the recommendations of Gerlach (1971) and McIntyre (1969). However, it differs from the conclusions of Vranken et al. (1986) who consider it to be too low. To convert from dry weight to carbon the relationship carbon content $=40 \%$ of dry weight (Steele 1974, Feller \& Warwick 1988) was used.

Conventional energy budget principles were employed to calculate nematode consumption. The energy flow through a nematode population can be written as: $C=P+R+G+U+F$ where $C=$ consumption, $P=$ production, $R=$ respiration, $U=$ soluble waste products, $F=$ particulate waste products and $G=$ 
gonad output. Since nothing is known about excretion in marine nematodes (Heip et al. 1985, Feller \& Warwick 1988) an assimilation efficiency of $60 \%$ was assumed, demonstrated by Marchant \& Nicholas (1974) for the bacteria-feeding Pelodera and adopted by Warwick et al. (1979) for their description of secondary production in the Lynher estuary. This allows the unassimilated energy factors $(U+F)$ to be discounted. Gonad output is the only unquantifiable component of the equation, and for the sake of this study energy bound up in the form of eggs and other reproductive products has been ignored; consumption figures should therefore be viewed as a minimum.

\section{DISCUSSION}

The total biomass figures calculated for the combined nematode feeding groups, although low for an estuarine system, are within the range of values quoted in the literature (see review by Lasserre et al. 1976); published values have often been formulated using data gathered during only one (usually summer) season, when standing stocks are likely to be high. The greater biomass from the Exe Estuary mud site reflects the higher productivity of this habitat when compared with coarser sand. The diversity of the system is lower (21 species as opposed to 30) and the species dominance more marked (Fig. 2), confirming what is already known about the community composition of such systems (Wieser 1960, Warwick 1971). The total

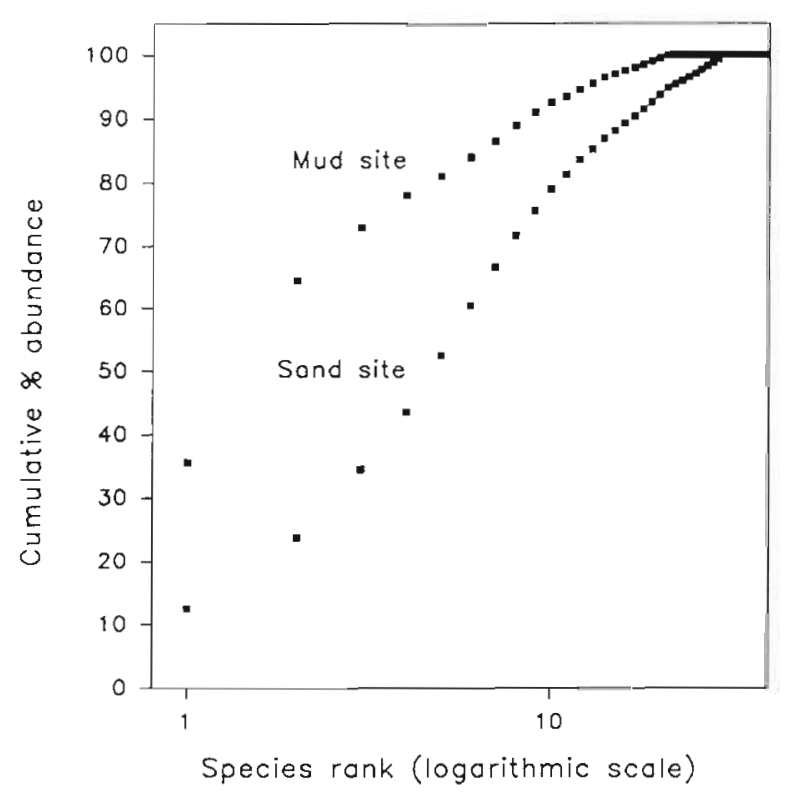

Fig. 2. K-dominance curves for Exe Estuary nematode communities

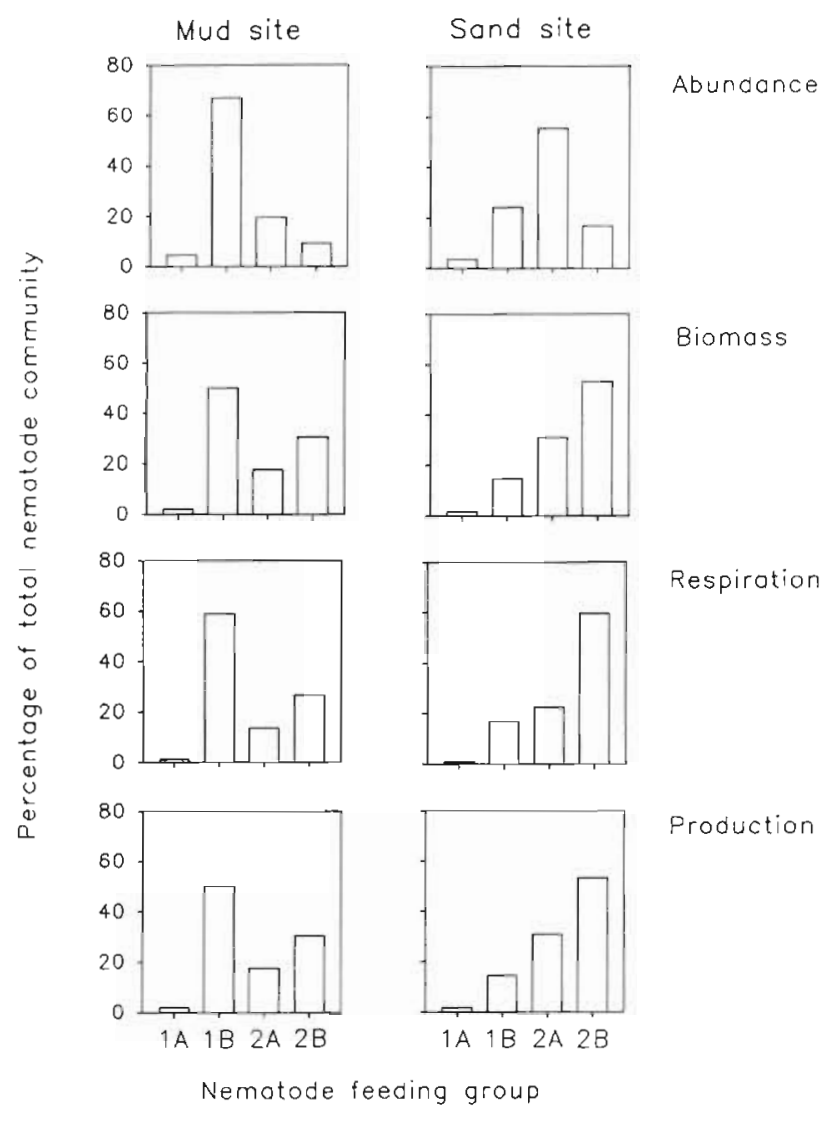

Fig. 3. Percentage importance, in terms of abundance, biomass, respiration and production, of Wieser's (1953) 4 nematode feeding groups at sand and mud sites in the Exe Estuary

community consumption figures of 7.05 (mud) and 5.41 (sand) $\mathrm{g} \mathrm{C} \mathrm{m}^{-2} \mathrm{yr}^{-1}$ compare realistically with a value of $29.71 \mathrm{~g} \mathrm{C} \mathrm{m}^{-2} \mathrm{yr}^{-1}$ obtained for the total meiofaunal community from a more densely populated estuary (Warwick et al. 1979).

The purpose of this study was to model the partitioning of carbon flow between nematode feeding groups. Carbon sources for nematode community nutrition could then be identified. If detritus and algae comprise the bulk of their diet then nematodes are unlikely to contribute significantly to the small food web. Conversely, if the energetic demand of omnivorous predatory nematodes is great, a significant role in the small food web may be predicted.

A summary of carbon partitioning in abundance, biomass, respiration and production terms is given in Fig. 3. The relative consumption of each feeding group in sand and mud substrata is shown in Fig. 4. The contrast between the importance of each group in abundance and energetic terms is considerable. For example, while in abundance terms epigrowth feeders comprise $55.6 \%$ of the sand nematode fauna, in con- 


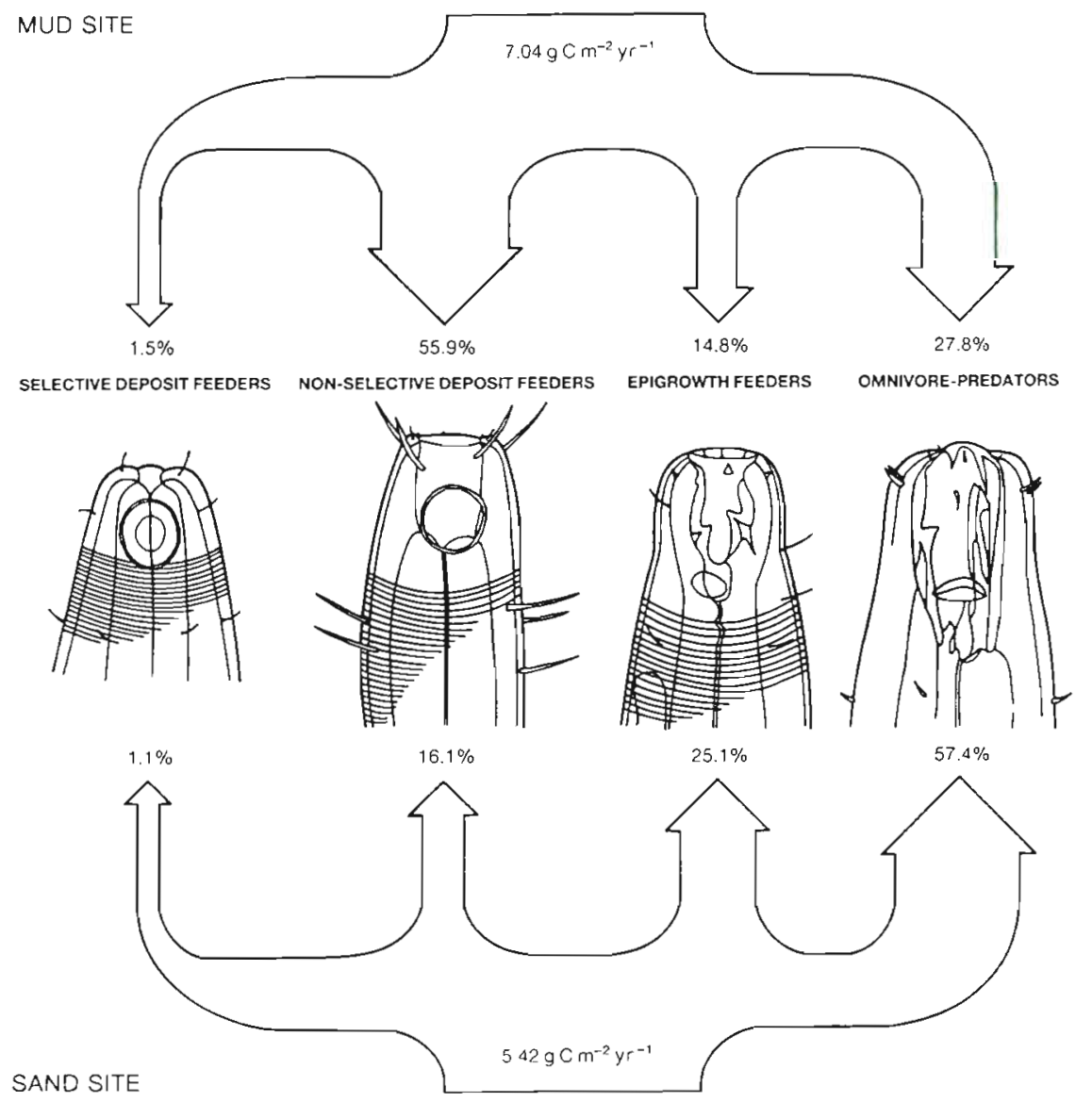

Fig. 4. Summary of partitioning of carbon consumption between nematode feeding groups in Exe Estuary sand and mud substrata (representative species redrawn from Platt \& Warwick 1980) sumption terms they account for only $25.1 \%$ of the carbon flow. Conversely omnivore predators, which comprise $16.7 \%$ of the sand nematode fauna, account for $57.4 \%$ of its consumption. These community patterns are reflected at the species level (Table 6). Enoploides brunetti, a sand-dwelling omnivore predator, although only 15 th in importance in numerical terms, is 2 nd in importance in consumption terms. Conversely Halalaimus gracilis, a mud-dwelling non-selective deposit

Table 6 . Ten most important nematode species, in consumption terms, at sand and mud sites in the Exe Estuary (values = percentage of total carbon consumed)

\begin{tabular}{|lrlr|}
\hline Sand site & \multicolumn{3}{l|}{ Mud site } \\
\hline Enoplolaimus proprinquus & 16.5 & Sabatieria pulchra & 38.2 \\
Enoploides brunetti & 15.9 & Sphaerolaimus hirsutus & 18.5 \\
Gammanema conicauda & 10.2 & Metalinhomoeus filiformis & 12.2 \\
Xyala striata & 7.9 & Viscosia viscosa & 7.6 \\
Oncholaimus brachycercus & 6.4 & Calyptronema maxweberi & 5.3 \\
Enoplolaimus denticulatus & 4.9 & Ptycholaimellus ponticus & 4.8 \\
Pomponema sedecima & 4.6 & Anoplostoma viviparum & 2.4 \\
Chromadora nudicapitata & 4.1 & Praeacanthonchus punctatus & 1.9 \\
Leptolaimus ampullaceus & 3.4 & Paralinhomeus tenuicaudatus & 1.9 \\
Neochromadora tecta & 3.0 & Dichromadora cephalata & 1.7 \\
& & & \\
\hline
\end{tabular}

feeder, is 6th in numerical importance and 16 th in consumption terms. By plotting the feeding modes of individual nematode species by their ranked contribution to total community consumption (Fig. 5) it can be seen that 2 omnivore-predator species (Enoplolaimus proprinquus and Enoploides brunetti) dominate the sand system, each with over $15 \%$ of the total consumption, while at the mud flat, although a single non-selective deposit feeder (Sabatieria pulchra) is dominant, omnivore-predators also play an important role.

These findings are of significance to whole-community benthic trophic dynamics. Where traditionally the functional role of nematodes has been thought to reflect the numerical domination by non-selective deposit feeders and epigrowth feeders in mud and sand substrata respectively, the present study suggests that, in energetic terms, the omnivore-predators, despite their low abundance, play an important role in both communities. This supports the findings of Warwick 


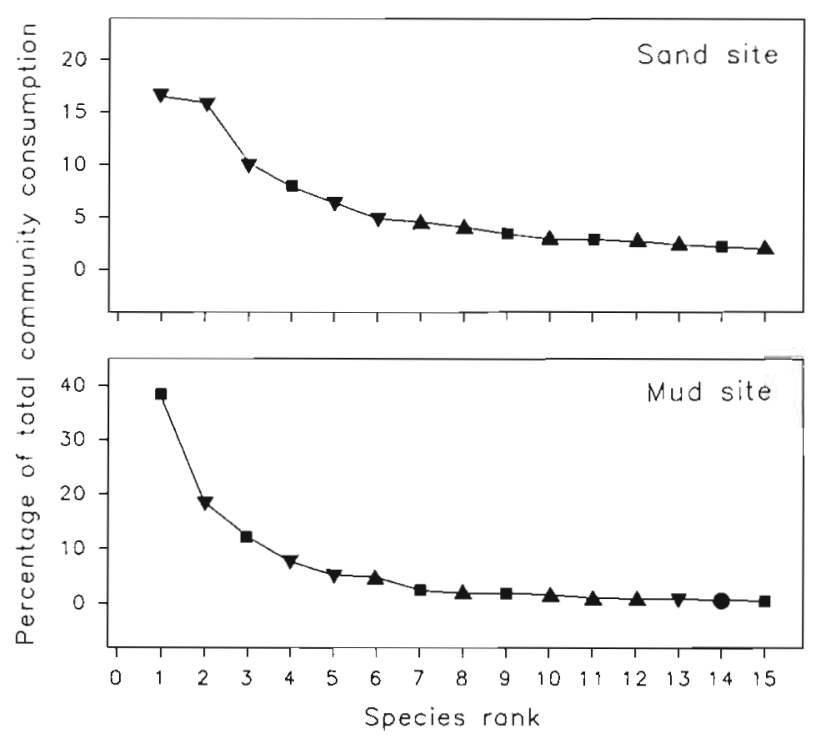

Fig. 5. Consumption-rank curves ( $\%$ of total consumption) for nematode species at sand and mud sites in the Exe

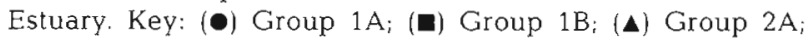
(v) Group 2B

(1982) and counters the traditional belief that detritus and sand-adhered algae provide the majority of nematode sustenance (see e.g. Mare 1942, Perkins 1958, Swedmark 1964). In energetic terms, small metazoa now seem likely to provide a significant meiofaunal food source. Wieser's omnivore-predator nematodes consume approximately 1.96 and $3.12 \mathrm{~g} \mathrm{C} \mathrm{m}^{-2} \mathrm{yr}^{-1}$ in the mud and sand substrata respectively. This is more than total nematode community production. Carbon cycling within the meiofauna must thus account for a significant proportion of benthic production. As Kuipers et al. (1981) suggest, this trophic pathway will not yield a considerable amount of secondary biomass but instead produce mainly heat and release nutrients.

One qualification is required to these conclusions: a central tenet of the study, resulting from the adoption of Wieser's (1953) classification scheme, is that a relationship exists between nematode buccal structure and diet. Nematode species with no buccal cavity (Group 1A) are predicted to consume only free particles of bacterial size. Species with unarmed buccal cavities (Group 1B) may ingest free particles of a larger size provided they require no mastication. Epigrowth feeders (Group 2A) with small rasping or piercing teeth may feed on algae, including diatoms. Omnivore predators, by virtue of their large powerful denticles (Group 2B), may prey upon other small metazoa. While substantial evidence exists to support this relationship (see e.g. von Thun 1968, Tietjen \& Lee 1975, Heip et al. 1978, Jensen 1982, Romeyn et al. 1983), including observations of the predatory habits of $2 \mathrm{~B}$ nematodes (see Lopez et al. 1979, Heip et al. 1985), the validity of the buccal morphology/diet relationship has recently been questioned (see Romeyn \& Bouwman 1983, Jensen 1987). Detailed research is required to evaluate the true nature of nematode diet so that the validity of modelling approaches, such as that used here, may be critically assessed.

Acknowledgements. This research was supported by grant no. GT4/87/ALS/53 from the UK Natural Environment Research Council. Facilities for the study were provided by Exeter University and Plymouth Marine Laboratory. Dr R. M. Warwick provided guidance on nematode taxonomy and much useful discussion.

\section{LITERATURE CITED}

Andrassy, I. (1956). Die Rauminhalts- und Gewichtsbestimmung der Fadenwürmer (Nematoden). Acta zool. hung. 2: $1-15$

Atkinson, H. J. (1980). Respiration of nematodes. In: Zuckerman, B. M. (ed.) Nematodes as biological models, Vol. 2. Academic Press, New York, p. 101-142

Austen, M. C. (1986). Factors affecting meiobenthic community structure in the Tamar estuary. Ph.D. dissertation, Exeter University

Banse, K., Mosher, S. (1980). Adult body mass and annual production/biomass relationships of field populations. Ecol. Monogr. 50: 355-379

Boalch, G. T (1980). Essays on the Exe Estuary. Spec. Vol. No. 2 of The Devonshire Association for the Advancement of Science, Literature and Art, Exeter

Bodin, P., Boucher, D., Guillou, J., Guillou, M. (1984). The trophic system of the benthic communities in the Bay of Douarnenez (Brittany). In: Proc. 19th Eur. Mar. Biol. Symp., p. $361-370$

Bovée, F. de (1987). Biomasse et équivalents énergétiques des Nématodes libres marins. Cah. Biol. mar. 28: 367-372

Coull, B. C., Bell, S. S. (1979). Perspectives of marine meiofaunal ecology. In: Livingstone, R. J (ed.) Ecological processes in coastal and marine ecosystems. Plenum, New York, p. 189-216

Crisp, D. J. (1984). Energy flow measurements. In: Holme, N. A., McIntyre, A. D. (eds.) Methods for the study of marine benthos, 2nd edn. IBP Handbook 16. Blackwell, Oxford, p. 284-372

Dickie, L. M. (1972). Food chains and fish production. In: Symposium on environmental conditions in the northwest Atlantic 1960-1969. Int. Comm. Northwest Atlantic Fish. Spec. Publ. No. 8, p. 201-221

Feller, R. J., Warwick, R. M. (1988). Energetics. In: Higgins, R. P., Thiel, H. (eds.) Introduction to the study of meiofauna. Smithsonian, Washington, DC, p. 181-196

Fenchel, T. (1978). The ecology of micro- and meiobenthos. A. Rev. Ecol. Syst. 9: 99-121

Gee, J. M. (1987). Impact of epibenthic predation on estuarine intertidal harpacticoid copepod populations. Mar. Biol. 96: $497-510$

Gerlach, S. A. (1971). On the importance of marine meiofauna for benthos communities. Oecologia 6: 179-190

Heip, C., Smol, N., Absillis, V. (1978). Influence of temperature on the reproductive potential of Oncholaimus oxyuris (Nematoda, Oncholaimidae). Mar. Biol. 45: 255-260 
Heip, C., Vincx, M., Smol, N., Vranken, G. (1982). The systematics and ecology of free-living marine nematodes. Helminth. Abstr. B 51.1-31

Heip, C., Vincx, M., Vranken, G. (1985). The ecology of marine nematodes. Oceanogr. mar. Biol. 23: 399-489

Hoff, J. H. van't. (1896). Studies in chemical dynamics. Muller, Amsterdam

Jensen, P. (1982). Diatom-feeding behaviour of the free-living marine nematode Chromadorita tenuis. Nematologica 28: $71-76$

Jensen, P. (1987). Feeding ecology of free-living aquatic nematodes. Mar. Ecol. Prog. Ser. 35: 187-196

Jonge, V. N. de, Bouwman, L. A. (1977). A simple density separation technique for quantitative isolation of meiobenthos using the colloidal silica Ludox-TM. Mar. Biol. 42: $143-148$

Kennedy, A. D. (1993). Minimal predation upon meiofauna by endobenthic macrofauna in the Exe Estuary, south west England. Mar. Biol. 117: 311-319

Kuipers, B. R., Wilde, P. A. W. J. de, Creutzberg, F. (1981) Energy flow in a tidal flat ecosystem. Mar. Ecol. Prog. Ser 5: $215-221$

Lasserre, P., Renaud-Mornant, J., Castel, J. (1976). Metabolic activities of meiofaunal communities in a semi-enclosed lagoon. Possibilities of trophic competition between meiofauna and mugilid fish. In: Proc. 10th Eur. Mar. Biol. Symp., Vol. 2. Ostend, p. 393-414

Lopez, G., Riemann, F., Schrage, M. (1979). Feeding biology of the brackish-water oncholaimid nematode Adoncholaimus thalassophygas. Mar. Biol. 54: 311-318

Marchant, R., Nicholas, W. L. (1974). An energy budget for the free-living nematode Pelodera (Rhabditidae). Oecologia 16: 237-252

Mare, M. F. (1942). A study of a marine benthic community with special reference to the study of micro-organisms J. mar biol. Ass. U.K. 25: 517-574

McIntyre, A. D. (1969). Ecology of marine meiobenthos. Biol Rev, 44: 245-290

McIntyre, A. D., Warwick, R. M. (1984). Meiofaunal techniques. In: Holme, N. A., McIntyre, A. D. (eds.) Methods for the study of the marine benthos, 2 nd edn. IBP Handbook 16. Blackwell, Oxford, p. 217-244

Myers, R. F. (1967). Osmoregulation in Pangrellus redivivus and Aphelenchus avanae. Nematologica 12: 579-586

Perkins, E. J. (1958). The food relations of the microbenthos with particular reference to that found at Whitstable, Kent. Ann. Mag. nat. Hist. 1: $64-77$

Platt, H. M., Warwick, R. M. (1980). The significance of freeliving nematodes to the littoral ecosystem. In: Price, J. H., Irvine, D. E. G., Farnham. W. F. (eds.) The shore environment, Vol. 2, Ecosystems. Academic Press, London, p. $729-759$

Price, R., Warwick, R. M. (1980). The effect of temperature on the respiration of meiofauna. Oecologia 44:145-148

Romeyn, K., Bouwman, L. A. (1983). Food selection and consumption by estuarine nematodes. Hydrobiol. Bull. 17: $103-109$

Romeyn, K., Bouwman, L. A., Admiraal, W. (1983). Ecology and cultivation of the herbivorous brackish-water nema-

This article was submitted to the editor tode Eudiplogaster pararmatus. Mar. Ecol. Prog. Ser 12: $145-153$

Schiemer, F., Duncan, A. (1974). The oxygen consumption of a freshwater benthic nematode Tobrilus gracilis (Bastian). Oecologia 15: 121-126

Steele, J. H. (1974). The structure of marine ecosystems. Blackwell, Oxford

Swedmark, B. (1964). The interstitial fauna of marine sand. Biol. Rev. 39: 1-42

Teal, J. M., Wieser, W. (1966). The distribution and ecology of nematodes in a Georgia salt marsh. Limnol. Oceanogr. 11: $217-222$

Tietjen, J. H. (1969). The ecology of shallow water meiofauna in two New England estuaries. Oecologia 2: 251-291

Tietjen, J. H., Lee, J. J. (1975). Axenic culture and uptake of dissolved substances by the marine nematode, Rhabditis marinea Bastian. Cah. Biol. mar. 16: 685-693

von Thun, W. (1968). Autökologische Untersuchungen an freilebenden Nematoden des Brackwassers. Dissertation, Univ. Kiel

Vranken, G., Heip, C. (1986). The productivity of marine nematodes. Ophelia 26: 429-442

Vranken, G., Herman, P. M. J., Vincx, M., Heip, C. (1986). A re-evaluation of marine nematode productivity. Hydrobiologia 135: 193-196

Warwick, R. M. (1971). Nematode associations in the Exe Estuary. J mar. biol. Ass. U.K. 51: 439-454

Warwick, R. M. (1981). The influence of temperature and salinity on energy partitioning in the marine nematode Diplolaumelloides bruciei. Oecologia 51: 318-325

Warwick, R. M. (1982). The partitioning of secondary production among species in benthic communities. Neth. J. Sea Res. 16: 1-16

Warwick, R. M., Joint, I. R., Radford, P. J. (1979). Secondary production of the benthos in an estuarine environment. In: Jeffries, R. L., Davy, A. (eds.) Proceedings of the First European Ecological Symposium: Ecological processes in coastal environments. Blackwell, Oxford, p. $429-450$

Warwick, R. M., Price, R. (1979). Ecological and metabolic studies on freeliving nematodes from an estuarine mudflat. Estuar. coast. mar. Sci. 9: 257-271

Waters, T. F. (1977). Secondary production in inland waters. Adv. ecol. Res. 10: 91-164

Wieser, W. (1953). Die Beziehung zwischen Mundhöhlengestalt, Ernährungsweise und Vorkommen bei freilebenden marinen Nematoden. Ark. Zool. 4: 439-484

Wieser, W. (1960). Benthic studies in Buzzards Bay. II. The meiofauna. Limnol. Oceanogr. 5: 121-137

Wieser, W., Kanwisher, J. W. (1961). Ecological and physiological studies on marine nematodes from a small salt marsh near Woods Hole, Massachusetts. Limnol. Oceanogr 6: 262-270

Wieser, W., Schiemer, F. (1977). The ecophysiology of some marine nematodes from Bermuda: seasonal aspects. J. exp. mar. Biol. Ecol. 26: 97-106

Zaika, V. E., Makarova, N. P. (1979). Specific production of free-living marine nematodes. Mar Ecol. Prog. Ser. 1: $153-158$

Manuscript first received: August 6, 1993

Revised version accepted: November 19,1993 